\title{
Pleural myopericytoma: A rare neoplasm in a difficult location
}

Kevin Hodges, MD, ${ }^{\mathrm{a}}$ Youran Zou, MB, ${ }^{\mathrm{b}}$ Andrew Everett, MD, ${ }^{\mathrm{a}}$ Sudish Murthy, MD, PhD, ${ }^{\mathrm{a}}$ and Usman Ahmad, MD, ${ }^{\text {a }}$ Cleveland, Ohio

From the Departments of ${ }^{\mathrm{a}}$ Thoracic and Cardiovascular Surgery and ${ }^{\mathrm{b}}$ Pathology, Cleveland Clinic Foundation, Cleveland, Ohio.

Disclosures: Authors have nothing to disclose with regard to commercial support.

Received for publication Oct 19, 2017; revisions received Dec 26, 2017; accepted for publication Jan 19, 2018; available ahead of print March 3, 2018

Address for reprints: Usman Ahmad, MD, Department of Thoracic and Cardiovascular Surgery, Cleveland Clinic Foundation, 9500 Euclid Ave, J4-1, Cleveland, OH 44195 (E-mail: ahmadu@ @cf.org).

J Thorac Cardiovasc Surg 2018;156:e129-31 $0022-5223 / \$ 36.00$

Copyright $(\subset) 2018$ by The American Association for Thoracic Surgery https://doi.org/10.1016/j.jtcvs.2018.01.072

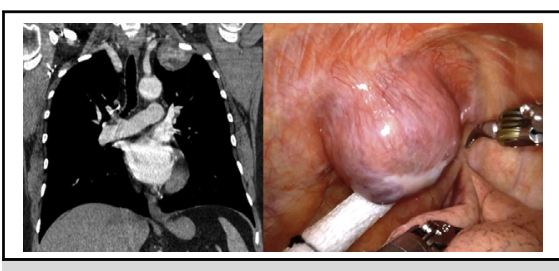

Coronal CT and intraoperative photograph demonstrating pleura-based myopericytoma.

\section{Central Message}

A 57-year-old woman had primary intrathoracic myopericytoma, which was discovered incidentally on a chest radiograph. The patient successfully underwent robotically assisted resection.

Video clip is available online.

See Editorial Commentary page e133.

The spectrum of pleural tumors is broad and comprises entities with varying degrees of malignant potential. Generally, solitary pleura-based tumors are treated with resection to alleviate symptoms, establish diagnosis, and exclude malignancy. Myopericytoma, a tumor that is rarely identified as a pleura-based lesion, may share radiographic and pathologic characteristics with solitary fibrous tumors. ${ }^{1}$ We present the case of a patient who underwent robotically assisted resection of a primary intrathoracic myopericytoma.

\section{CLINICAL SUMMARY}

A 57-year-old woman presented for evaluation of a pleura-based mass identified incidentally on a chest radiograph. Her medical history was remarkable only for uterine fibroids, for which she had undergone a hysterectomy. At

the time of presentation, she had a 2-month history of dry cough and persistent dyspnea. Axial computed tomographic imaging showed a $3 \times 4 \times 3-\mathrm{cm}$ apical, pleura-based mass with smooth margins (Figure $1, A$ and $B$ ) that did not demonstrate fludeoxyglucose $\mathrm{F} 18$ (INN fludeoxyglucose $\left.\left[{ }^{18} \mathrm{~F}\right]\right)$ uptake. A core-needle biopsy sample was consistent with solitary fibrous tumor. Magnetic resonance imaging was performed to assess neurovascular involvement and demonstrated abutment of the brachial plexus and close proximity to the subclavian vessels without neurovascular encasement (Figure 1,B). Because of the risk of malignancy or malignant transformation, robotically assisted thoracoscopic resection, was offered with the plan to convert to

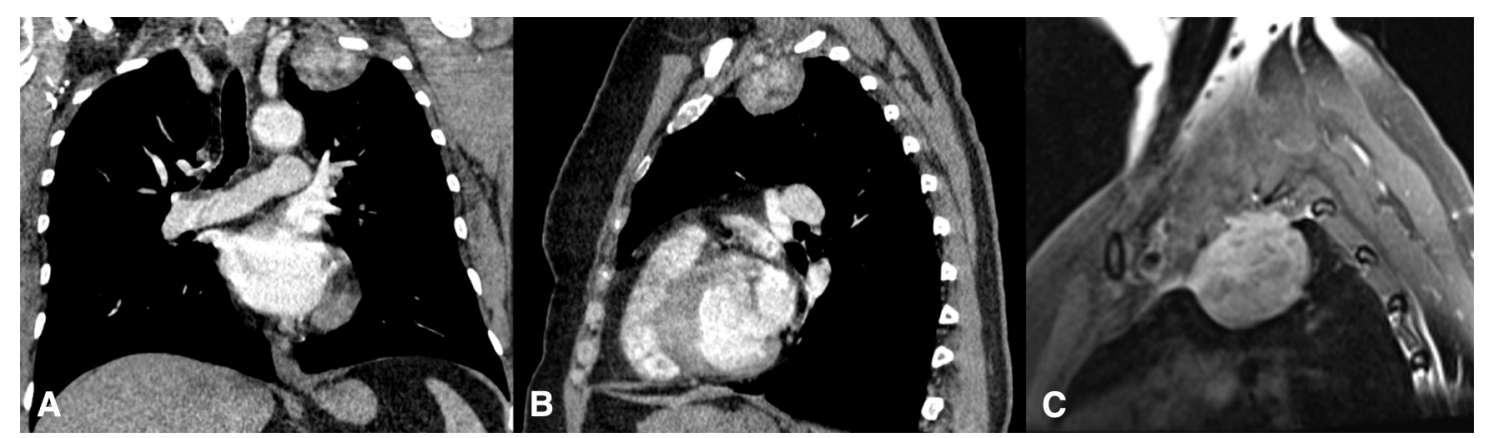

FIGURE 1. A and B, Computed tomography demonstrates a heterogeneous, pleura-based mass at the apex of the left side of the chest that lies in close proximity to the left axillary artery. C, Postcontrast T1 magnetic resonance imaging demonstrates an enhancing lesion that abuts the brachial plexus without neurovascular encasement. 

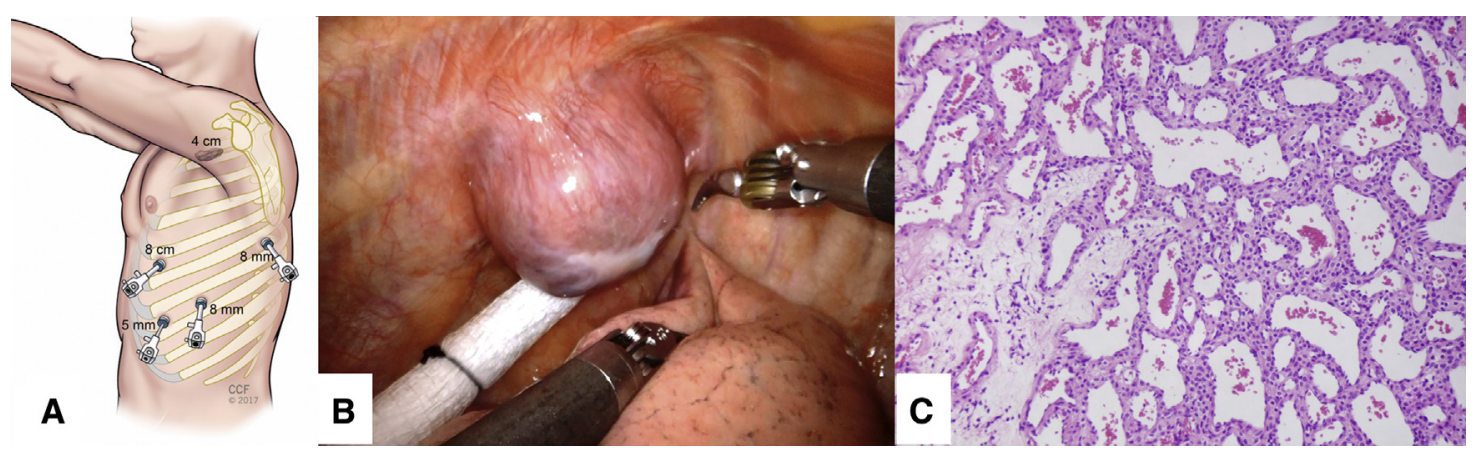

FIGURE 2. A, Robotic port placement. B, Intraoperative photograph of the mass, which was well encapsulated and rich in vascular component. C, Representative histologic section with hematoxylin and eosin stain, demonstrating a tumor composed of uniform cells with a prominent hemangiopericytomalike vascular pattern.

left hemiclamshell in case of significant subclavian artery involvement.

The patient underwent elective robotically assisted resection of the tumor. She was positioned in the right lateral decubitus position and securely taped to the operating table, with padding on both sides such that table could be rotated significantly without the risk of the patient moving off the table. In the event of emergency conversion to left hemiclamshell, the plan was to rotate the operating table steeply to the left to facilitate exposure. A camera port was placed in the seventh intercostal space, robotic instrument ports in the sixth space, and an assistant port in the eighth intercostal space. The tumor was encapsulated and adherent to the adventitia of the subclavian artery as it traversed the apex of the left side of the chest (Figure 2). There was a network of collateral vessels arising from the pleura and chest wall, which were controlled with a series of clips. The internal thoracic artery was identified and preserved. The tumor

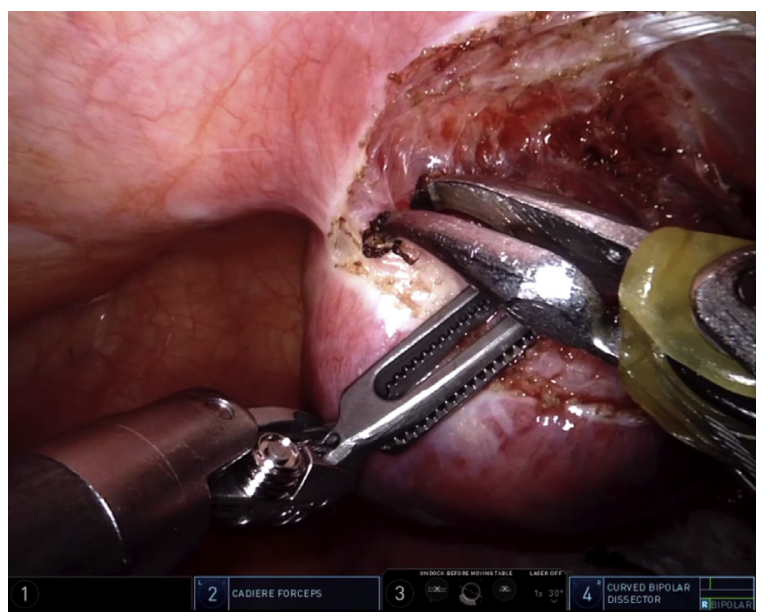

VIDEO 1. Intraoperative video demonstrating robotically assisted resection of an apical myopericytoma at the thoracic inlet. Video available at: http://www.jtcvsonline.org/article/S0022-5223(18)30337-4/fulltext. was dissected from the subclavian artery adventitia with bipolar electrocautery. A plane was developed between the tumor capsule and the subclavian artery adventitia, and both structures were successfully preserved. The dissection was intentionally kept in the periadventitial plane of the subclavian artery, and the brachial plexus was not encountered during dissection. Several small feeding vessels were ligated, and the tumor was completely excised (Video 1). Postoperative recovery was uneventful, and the patient was discharged home on postoperative day 2 .

Pathologic evaluation demonstrated a tumor composed of uniform cells with a prominent hemangiopericytomalike vascular pattern. Lesional cells were negative for S100 protein, desmin, AE1/AE3, and CD31. CD34 highlighted the vessels with weak and patchy positivity in the tumor cells. The tumor cells were strongly positive for smooth muscle actin (SMA) and negative for STAT6, supporting a diagnosis of myopericytoma.

\section{DISCUSSION}

Myopericytoma represents a rare entity with hemangiopericytoma-like vascular pattern, which primarily affects the skin and soft tissues of the extremities. Less commonly, these tumors are identified affecting the head, neck and trunk. ${ }^{1}$ The lesional cells are related to myopericytes, contractile cells that surround capillaries and small vessels. $^{2}$ They are defined by specific histopathologic criteria, including smooth muscle actin positivity. ${ }^{3}$ To date, there have been only a small number of case reports of primary intrathoracic myopericytomas (Table 1). ${ }^{4-7}$ There are no data on the clinical characteristics of intrathoracic myopericytoma, but extrapolation from tumors of the extremities and head and neck suggest that these lesions tend to follow on indolent course. In a series of 46 patients with median follow up of 48 months (range 7-168), Mentzel and colleagues ${ }^{3}$ found that despite marginal or incomplete excision in 23 of 46 cases, only two myopericytomas recurred locally. Nevertheless, there have been reports of 
TABLE 1. Case reports of primary intrathoracic myopericytomas, excluding tumors of the thoracic spine, in English-language journals

\begin{tabular}{|c|c|c|c|}
\hline Reference & Clinical and anatomic details & Treatment approach & Outcome \\
\hline Cao et $\mathrm{al}^{4}{ }^{4} 2009$ & Right lower lobe lung nodule, asymptomatic & $\begin{array}{l}\text { Right lower lobectomy for suspected } \\
\text { primary lung cancer }\end{array}$ & $\begin{array}{l}\text { Alive with no } \\
\text { recurrence at } 3 \mathrm{y}\end{array}$ \\
\hline $\begin{array}{l}\text { Edgecombe } \\
\text { et al, }{ }^{5} 2011\end{array}$ & $\begin{array}{l}\text { Pleura-based right upper lobe nodule, asymptomatic, } \\
\text { enlarging during } 5 \text { y of follow-up, core biopsy } \\
\text { suggested myopericytoma }\end{array}$ & Right upper lobe wedge resection & $\begin{array}{l}\text { Alive with no } \\
\text { recurrence at } 3 \mathrm{y}\end{array}$ \\
\hline $\begin{array}{l}\text { Song } \\
\quad \text { et al, }{ }^{6} 2012\end{array}$ & $\begin{array}{l}\text { Multiple bilateral lung nodules, symptoms of dry } \\
\text { cough without dyspnea }\end{array}$ & $\begin{array}{l}\text { Bronchoscopy followed by multiple } \\
\text { pulmonary wedge resections for } \\
\text { diagnosis and treatment }\end{array}$ & $\begin{array}{l}\text { Alive with no } \\
\text { recurrence at } 3 \mathrm{y}\end{array}$ \\
\hline $\begin{array}{l}\text { Mainvill } \\
\quad \text { et al, }{ }^{7} 2015\end{array}$ & $\begin{array}{l}\text { Malignant left atrial tumor with brain, thoracic spine, } \\
\text { and liver metastases, presented with CNS } \\
\text { symptoms }\end{array}$ & $\begin{array}{l}\text { Staged resection of primary tumor, } \\
\text { occipital lobe metastasis, and } \\
\text { thoracic spinal metastasis }\end{array}$ & $\begin{array}{l}\text { Alive at } 8 \text { mo with extensive } \\
\text { metastatic disease }\end{array}$ \\
\hline
\end{tabular}

A PubMed search was conducted for articles containing "myopericytoma" in the title; all results were reviewed for inclusion. CNS, Central nervous system.

malignant myopericytoma. McMenamin and Fletcher ${ }^{8}$ reported a series of 5 patients with malignant myopericytoma; 4 patients had metastases develop, and 3 died within 1 year. Malignant myopericytoma was defined by high mitotic rate and myoid-appearing ovoid to spindle cells showing at least focally striking perivascular orientation as in benign myopericytoma.

Myopericytoma represents a rare intrathoracic neoplasm, which may easily be mistaken for solitary fibrous tumor based on imaging characteristics. The clinical implications of this entity have not been defined. Myopericytomas seem to have some degree of malignant potential, however, so complete resection should be considered.

Multiple published series have demonstrated that pleurabased tumors can be safely resected with minimallyinvasive techniques. In such reports, resection margin and oncologic outcome have not been shown to vary by surgical approach. Data on robotically assisted techniques for the resection of chest wall tumors are sparse, but extrapolation from the thoracoscopic surgery literature would suggest that robotic resections can be performed with similar outcomes. Dense tumor adhesions can make resection challenging in proximity to neurovascular structures. In case of minimally invasive resections, it is important to be prepared to achieve open vascular exposure.

\section{References}

1. Dray MS, McCarthy SW, Palmer AA, Bonar SF, Stalley PD, Marjoniemi V, et al Myopericytoma: a unifying term for a spectrum of tumours that show overlapping features with myofibroma. A review of 14 cases. J Clin Pathol. 2006;59:67-73.

2. McMenamin M, Calonje E. Intravascular myopericytoma. J Cutan Pathol. 2002; 29:557-61.

3. Mentzel T, Dei Tos AP, Sapi Z, Kutzner H. Myopericytoma of skin and soft tissues: clinicopathologic and immunohistochemical study of 54 cases. Am J Surg Pathol. 2006;30:104-13.

4. Cao JH, Xu JP, Li YC, Lai J, Li Q. Pulmonary myopericytoma: a case report and review of the literatures. Chin Med J (Engl). 2009; 122:755-7.

5. Edgecombe A, Peterson RA, Shamji FM, Commons S, Sekhon H, Gomes MM Myopericytoma: a pleural-based spindle cell neoplasm off the beaten path. Int $J$ Surg Pathol. 2011;19:247-51.

6. Song XL, Sun XY, Zhang GL, Yu YW, Wang CH. Myopericytoma presenting as multiple pulmonary nodules. Intern Med. 2012;51:639-42.

7. Mainville GN, Satoskar AA, Iwenofu OH. Primary malignant myopericytoma of the left atrium - a tumor of aggressive biological behavior: report of the first case and review of the literature. Appl Immunohistochem Mol Morphol. 2015;23:464-9.

8. McMenamin ME, Fletcher CD. Malignant myopericytoma: expanding the spectrum of tumours with myopericytic differentiation. Histopathology. 2002;41 450-60. 